\title{
Responsivt forældresamarbejde i skolen
}

\author{
Gro Emmertsen Lund, selvstændig konsulent, ph.d., Taos Associate \\ og en del af NO!SE. E-mail: gel@groemmertsenlund.dk
}

\begin{abstract}
Resume
Responsivt forældresamarbejde handler om skolens måde at møde og samarbejde med elevernes forældre på. For skolens professionelle er forældresamarbejdet en del af kerneopgaven. Undersøgelser viser dog, at samarbejdet ofte opleves svært og krævende, hvilket kan have store negative konsekvenser for de implicerede, ikke mindst familierne. Responsivt forældresamarbejde tager afsæt i de professionelles ansvar og kompetencer og lægger fokus på de forholdemåder og handlinger, hvormed de professionelle indgår i og faciliterer samarbejdsprocesser med forældrene. Artiklen redegør for, hvad responsivt forældresamarbejde betyder, og hvordan det kan se ud i praksis. Artiklen viser, hvordan de dominerende diskurser om forældresamarbejde stiller sig hindrende i vejen for et responsivt forældresamarbejde. Hermed argumenteres for et behov for en ny diskurs, som artiklen forsøger at give et bud på.
\end{abstract}

Nøgleord: forældresamarbejde, forældreperspektiver, diskurser, responsiv, skole-hjem-samarbejde, skoleudvikling, skolekultur

\begin{abstract}
Responsive parent collaboration has to do with the ways in which schools collaborate with parents. For school professionals it is part of the job to collaborate with parents, however research shows that this is often perceived as difficult and troublesome. Hence, difficult collaboration can have many negative consequences for all parties, not least for the families. Responsive parent collaboration is based on the responsibilities and competencies of the school professionals, and thus focuses on the ways of thinking and the actions by which the professionals enter into and facilitate cooperation with parents. The article explains what responsive parent collaboration means, and what it might look like in practice. The article shows how five dominant discourses in parent collaboration are hindering a responsive relationship. Hereby it is argued that a new discourse is needed, and the article offers an image of what that might be.
\end{abstract}

Keywords: discourses, parent collaboration, parent perspectives, responsiveness, school-family collaboration, school development, school culture. 


\section{Hvad betyder responsivt forældresamarbejde?}

Responsivt forældresamarbejde handler om skolens måde at møde og samarbejde med elevernes forældre på. Jeg hørte om responsiveness to parents for nogle år siden, da jeg var på skolebesøg i Ontario, Canada. Responsiveness to parents blev beskrevet som at være lydhør og lytte til forældrene, altså til dét, de siger og har på hjerte. Men også at stille spørgsmål, fx spørge, hvad forældrenes dårligste oplevelser med skolen er, og hvilke forbedringsforslag de har, samt spørge til, hvordan de involverer sig i skolen. At spørge til skolens svagheder virkede på mig radikalt og potentielt risikabelt. Hvorfor ikke nøjes med at spørge til, hvad forældrene oplevede som skolens styrker? Men netop dette med at være lydhør overfor kritik og at forsøge at forbedre er selve essensen i det responsive forældresamarbejde. 'Respons' kommer fra det latinske responsum, der kan oversættes til at respondere, det vil sige svare på, reagere på eller handle på. Det er ikke nok at lytte, imødekomme og inddrage, skolen skal også gøre noget med det, forældrene siger. To af de store strategiske organisationskonsulenter bag skoleudviklingen i Ontario, Michael Fullan og Andy Hargreaves, påpeger, at responsiveness to parents er afgørende for, at skoler kontinuerligt kan forbedre sig og udvikle sig i tråd med og til gavn for elevers sociale og personlige udvikling og læringsudbytte (Hargreaves \& Fullan, 2012). Responsivt forældresamarbejde understøtter organisatorisk læring og praksisudvikling og indlejrer sig dermed i en proaktiv skolekultur, hvor elev- og forældrestemmer, mangfoldighed og forskellighed værdsættes som bidrag til udvikling af skolens praksis (Lund \& Haslebo, 2015; Lund \& Winslade, 2018; Lund, 2020b).

Fundamentet i responsivt forældresamarbejde er forældres og elevers formelle og juridiske rettigheder, dvs. retten til at blive hørt, retten til at blive lyttet til, retten til inddragelse og medbestemmelse, retten til at kende til sine rettigheder, herunder klagemuligheder, samt retten til tilpasset undervisning med reel undervisningsadgang og udbytte, herunder sygeundervisning, støtte m.m. Disse rettigheder er formuleret og beskyttet af en række konventioner, love og erklæringer, så som FN's børnekonvention, Menneskerettighedskonventionen, Handikapkonventionen, Folkeskoleloven, Inklusionsloven, Undervisningsmiljøloven, Salamanca-erklæringen, Serviceloven samt forvaltningsretslige regler (Nielsen et al., 2017). Dernæst bygger responsivt forældresamarbejde på en relationel etik (Haslebo \& Haslebo, 2007), det vil sige etiske overvejelser og anerkendende antagelser om alle familier, forældre og børn. Her tages der udgangspunkt i elevers og forældres ret til at 
blive mødt med positive forventninger, og der tilbydes positioner, hvorfra de rent faktisk kan bidrage og samarbejde (Lund, 2017).

I det følgende vil jeg redegøre for, hvorfor der er brug for responsivt forældresamarbejde, og hvad det kan siges at være et opgør med, altså hvad det forsøger at adskille sig fra.

\section{Hvorfor er der brug for responsivt forældresamarbejde?}

Af Folketingets Ombudsmands beretning (2016) fremgår det, at børns og forældres rettigheder krænkes i folkeskolers håndtering af alvorligere skoleproblemer, bl.a. retten til at blive hørt (partshøring). Ombudsmanden har flere gange i perioden fra 2012-2016 gjort opmærksom på forholdene. Problemet findes også på friskoler, efterskoler og andre private skoler, hvor Ombudsmanden har rejst problemstillingen over for ministeriet i 2014, 2016 og senest i 2019.

Institut for Menneskerettigheder (Nielsen et al., 2017) har undersøgt, hvordan samarbejdet mellem skole og forældre er i sager, hvor elever med ADHD og autisme er endt i fravær og skolevægring. Her er det gennemgående billede, at forældre ikke oplever sig hørt eller taget alvorligt, men mødes med mistro og bebrejdelser fra skolen, når deres børn kommer i skoleproblemer. En forælder fortæller: "Skolen blev ved med at tysse mig ned og tog slet ikke mine bekymringer alvorligt" (Nielsen et al., 2017, s. 48). En anden forælder beskriver: "Det var svært at opnå troværdighed omkring mine vurderinger" (Nielsen et al., 2017, s. 48). Den mistillid, som forældrene oplever fra skolen, når de fortæller om barnets reaktioner på skolemistrivsel, er ødelæggende for samarbejdet. Ofte viser udfordringerne sig i hjemmet først eksempelvis ved, at barnet forsøger at undgå at komme i skole om morgenen eller på anden måde fortæller forældrene om problemer i skolen. Det er derfor paradoksalt, at forældrenes bekymringer og bøn om hjælp fra skolen ikke mødes, men at det snarere lader til, at forældre oplever det modsatte. Det går også igen i flere af problemsagerne, at forældrene oplever, at skolen placerer grunden til barnets skoleproblemer hos forældrene. Forældrenes tillid til skolen udfordres af skolernes manglende indsats for at hjælpe barnet tilbage i skole(trivsel). Forældrene oplever, at skolerne ikke har de fornødne kompetencer til at skabe et undervisningsmiljø, der inkluderer deres barn. Samtidig oplever forældrene at være de bærende kræfter i forhold til at få iværksat foranstaltninger, der skal sikre, at undervisning af deres barn bliver mulig. Nielsen et al. (2017) fastslår, at uenigheden får: 


\begin{abstract}
.. forskellige konsekvenser $i$ sagerne, hoor forældrene i enkelte sager $f x$ trues med sociale foranstaltninger eller udelukkes fra den almindelige kontakt med skolen og de øvrige forældre i barnets klasse. I en sag udelukkes moren fra ForældreIntra, uden at det bliver gjort klart, hvordan det så sikres, at hun modtager relevant information. I en anden sag fratager skolelederen forældrene muligheden for at kommunikere direkte med barnets lærere, grundet at lærerteamet føler sig trængt op $i$ et hjørne. (Nielsen et al., 2017, s. 49)
\end{abstract}

Sådanne beretninger går igen i min ph.d.-forskning (Lund, 2017), hvor forældre gøres ansvarlige for skoleproblemer og for at løse dem hjemmefra og også afskæres fra kommunikation med læreren. Som Nielsen et al. (2017) påpeger $\mathrm{i}$ rapporten, er det $\mathrm{i}$ en rettighedsoptik problematisk, at medarbejdernes følelser får betydning for barnets ret til hjælp og samarbejdet med forældrene. Her ligger for mange ledere et dilemma mellem at skulle leve op til forventningen om at være den gode leder for medarbejderen i konfliktsager med forældre, det vil sige at beskytte og skærme, samt at være en god leder for skolens kerneopgave, det vil sige børns læring og skoletrivsel, herunder en god samarbejdspartner for forældre til børn i skoleproblemer.

\title{
Når skolehjemsamarbejdet kører af sporet
}

Det er velbelyst, at samarbejdet rummer udfordringer for skolerne, men også for familierne (Akselvoll, 2018; Knudsen, 2008a, 2008b, 2010; Lund, 2017; Nielsen et al., 2017). I samspilsproblemer i skolen og mellem skole og forældre peger Smyth \& Hattam (2004), Sibley (1995) og Roman (1996) på, at de mest oversete, men også vigtigste perspektiver i forhold til at skabe viden om problemerne er de involverede elever og forældres. Sibley (1996) forklarer, at for at forstå eksklusion og marginalisering må vi se på de ekskluderedes perspektiver på skolens praksis, herunder rammer, regler og begrænsninger for udfoldelse og deltagelse i skolen.

I min ph.d. har jeg undersøgt ressourcestærke middelklassefamiliers oplevelser og perspektiver på samarbejdet med skolen i relation til skolens håndtering af barnets mistrivsel i skolen, og hvor resultatet stik imod intentionerne blev eksklusion. Fælles for familierne var, at de alle oplevede ikke at blive lyttet til, ikke at blive taget alvorligt, men mistænkeliggjort og pålagt ansvaret for at være skyld i barnets skolemistrivsel og ansvaret for at løse problemet hjemmefra. Fælles for familierne var også, at samarbejdet med 
skolen gik i hårdknude, og at familierne derfor til sidst ikke så anden udvej end at flytte barnet til en anden skole. Eksklusionsprocessen forløber over seks trin (Lund, 2017) (se figur 1).

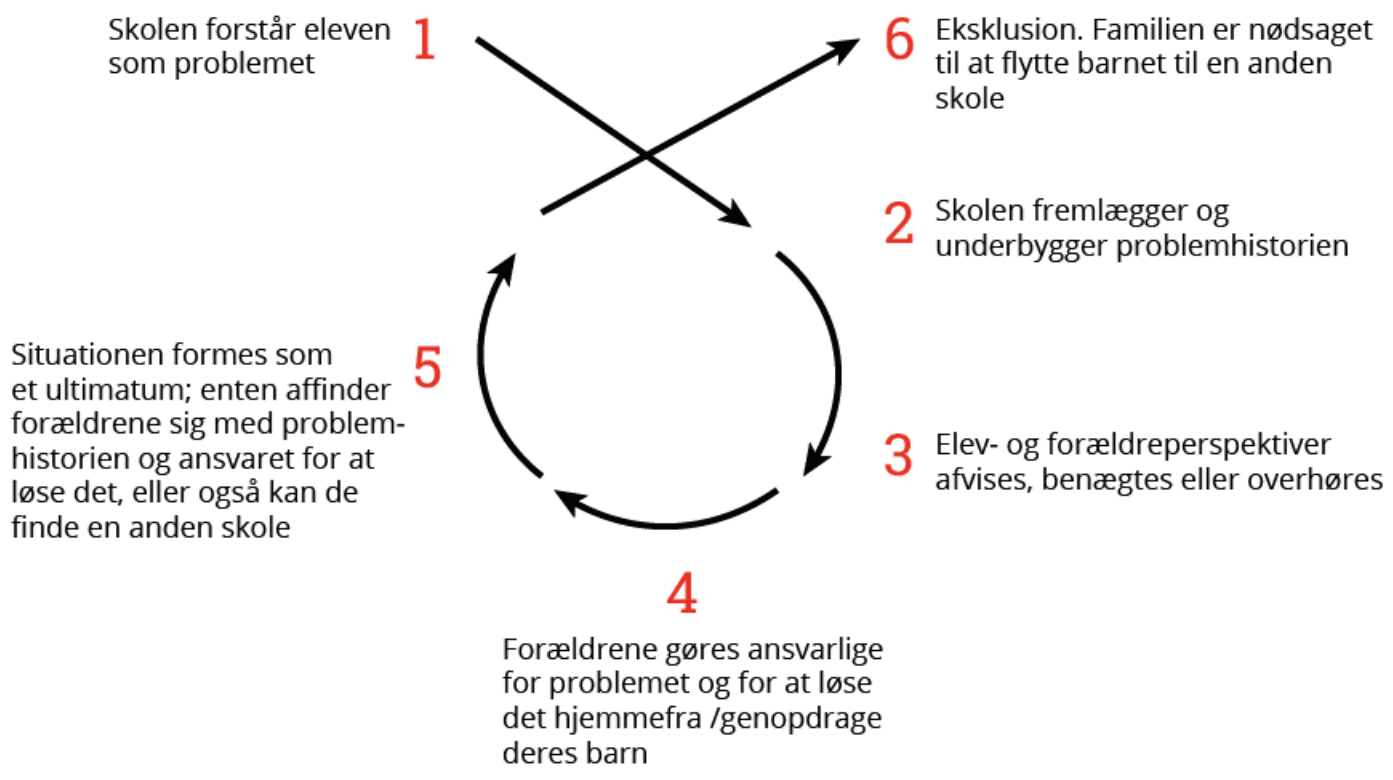

Figur 1. Eksklusionsspiralen

Når skolehjemsamarbejdet ender med skoleskift, er der i realiteten tale om en proces, hvori eleven og dennes forældre har været i løbende dialog med skolen, det man på nogle skoler kalder det udvidede samarbejde.

Det er ulykkeligt for alle involverede at være fanget i en eksklusionsproces. Både de elever og forældre, der rent faktisk ekskluderes, og de elever og forældre, hvor eksklusionsprocesserne står på i årevis, men ikke indebærer det sjette trin. Det er også uhensigtsmæssigt for klassens øvrige elever, der tages som gidsler og som vidner til en eksklusionskultur. Ikke mindst er det ulykkeligt for skolens lærere og pædagoger, idet det er slidsomt og nedbrydende at tage del i og være fanget i et negativt samspil. Ingen lærer, pædagog eller leder ønsker, at forældresamarbejdet skal føre til eksklusion, men det sker alligevel ind i mellem. Hvor stort er problemet mon? Ved grundskolens afslutning har omkring halvdelen af eleverne skiftet skole en eller flere gange; blandt dem er mistrivsel årsag til skoleskift i mere end hvert tredje (36 procent) tilfælde (Ottosen et al., 2010). Som min forskning viser, kæmper familierne for at undgå skoleskiftet, men også for at blive hørt, lyttet til og 
taget alvorligt som ambassadører for deres barn og legitime samarbejdspartnere for skolen. I det følgende skal vi se på, hvorfor det mon i mange tilfælde forekommer så svært.

\section{Dominerende diskurser i skolehjemsamarbejdet}

En diskurs kan forstås som en klynge af udsagn, grundlæggende antagelser og metaforer, der tegner en bestemt forståelse af virkeligheden samt skaber bestemte positioner og definerer et mulighedsrum for handlinger. Diskurser er indlejret i den dominerende kultur og indeholder elementer, der ofte ikke er italesat, og derfor kræver det et særligt blik og et særligt arbejde at opdage dem (Haslebo \& Lund, 2014).

Den danske forsker Hanne Knudsen analyserede 100 års love, vejledninger, bekendtgørelser og faglitteratur samt koncepter for konkrete aktiviteter: den årlige skole-hjem-samtale, påtale på kontoret, træning i den vanskelige samtale, familieklassen og ansvarsspillet. Dertil foretog hun observationer og interviews på to skoler (Knudsen, 2008a, 2008b, 2010). På den baggrund fandt hun fem dominerende diskurser, som desværre viste sig ubrugelige for det gode skole-hjem-samarbejde, nemlig pligtdiskursen, opbakningsdiskursen, deltagelsesdiskursen, omstillingsdiskursen og ansvarsdiskursen. Ingen af diskurserne er hjælpsomme i forhold til etablering af en samarbejdsrelation mellem skole og forældre, men de praktiseres alligevel alle mere eller mindre i dag - ofte i forskellige kombinationer (Haslebo \& Lund, 2014). En diskurs rummer ikke bare antagelser om fx skole og hjem, men positionerer også parterne og definerer normer for god adfærd. Fx lægger opbakningsdiskursen op til, at skolens professionelle kan forlange opbakning fra forældrene, også selvom de beslutninger, som skolen træffer, ikke tilgodeser deres barns situation i skolen. Deltagelsesdiskursen lægger op til, at forældre engagerer sig i skolens aktiviteter, fx via forældrearrangementer, trivselsindsatser m.m., men ikke gives egentlig indflydelse på væsentlige beslutninger med konsekvens for elevernes trivsel. Pligtdiskursen lægger op til, at forældrene afleverer et undervisningsparat barn, der kan indordne sig skolens standarder. Kan barnet ikke det, lægger diskursen op til den konklusion, at forældrene har svigtet deres opdragelsesopgave. Ansvarsdiskursen lægger op til, at forældre ansvarliggøres for børns skoleproblemer eller konflikter mellem børn i skolen, også selvom forældre ikke har indflydelse på de processer, der foregår i skolen. De fem diskurser sætter uklare rammer for forældresamarbejdet, italesætter uklare og urimelige forvent- 
ninger til forældrene og indeholder dermed masser af potentiale for konflikt. Men de lægger også op til negative måder at tænke og tale om forældre på. Konklusionen på diskursanalysen er, at når skoler fungerer inden for de fem dominerende diskurser, bliver det vanskeligt eller umuligt for skolen at leve op til sit lovgivningsbestemte ansvar for at etablere et godt samarbejde med forældre. Der er brug for en ny diskurs.

\section{Negative måder at tale (og tænke) om forældre på}

Der er et væld af negative kategorier, når talen falder på forældre: curlingforældre, speltmødre, de fortravlede forældre, de socialt belastede, de egoistiske, de besværlige, de kritiske, de urimelige osv. Negative måder at tale og tænke om forældre på har sneget sig ind i mange sammenhænge, bl.a. i politik og den offentlige debat, som indimellem får karakter af forældrebashing.

Negative måder at tale og tænke om forældre på fører let til forråelse samt mistænkeliggørelse af forældrenes evner, intentioner og handlinger. Thastum (2019) trækker også på negative måder at tale om forældre på i sin definition af den slags fravær, som han kalder tilbageholdelse. Det forlyder, at forældre der tilbageholder deres barn fra skolen, enten er kritiske; har overdrevne forestillinger om, at det er farligt for barnet at være i skolen; er syge, udnytter barnet som sygepasser eller husholderske; er psykisk syge eller socialt afvigende; ikke magter at påtage sig ansvar; er hjemløse eller misbrugere (s. 19). De meget negative måder at omtale forældrene på positionerer dem som skyldige og skurkagtige - og positionerer dermed børnene som ofre og skolen som passivt, uskyldigt og uansvarligt vidne (til forældrenes tilbageholdelse af barnet). Men kunne det tænkes, at forældrene har gode grunde til at lade barnet udeblive fra skole?

I min forskning ses forældre, der stærkt påtvunget og med store negative konsekvenser til følge må acceptere, at forholdene på skolen er så ubærlige for barnet, at det er bedre for barnet at blive hjemme. Forældrene ser det ikke som en tilbageholdelsesstrategi, men som en midlertidig løsning, mens de kæmper for at få ændret forholdene i skolen eller finde en anden skole til barnet (Lund, 2017). Begrebet tilbageholdelse, som det defineres af Thastum, levner ingen plads til, at forældrene kan have gode grunde til at lade barnet blive hjemme. De negative måder at tale om forældre på umuliggør en position, hvorfra de kan bidrage og samarbejde. Heller ikke skolens professionelle gives et godt udgangspunkt for samarbejdet, når måder at tænke og tale på om forældre er negative. Roman (1996) kritiserer dominerende negative konstruktioner af børn og deres forældre for at være stærkt problematiske, 
idet de udelukker og umuliggør børns og forældres muligheder for at mene og sige noget - selv når de inviteres med rundt om bordet. Han omtaler dette som en repræsentationskrise, der gør, at forældre og elever strukturelt fremmedgøres, nedgøres og forties. Roman påpeger, at det nærmest er umuligt for børn og forældre at afvise eller undgå den negative positionering, som dominerende negative diskurser medfører. Danske og norske forskere finder samme problemstilling, hvor elever ikke får taletid, men bliver talt "hen over hovedet", fx til de årlige skole-hjem-samtaler, hvor i øvrigt forældreperspektiver også forties, idet børnenes deltagelse på møderne gør, at forældrene afholder sig fra at stille kritiske spørgsmål eller rejse bekymring (Dannesboe et al., 2012; Knudsen, 2008a, 2008b, 2010; Madsen, 2012; Nordahl, 2008). Ligeledes finder Akselvoll (2018), at det generelt er svært for forældre at fremføre kritik i skolens rum, ligesom Dannesboe et al. (2012) finder, at forældre undlader at rejse spørgsmål eller fremføre kritik af frygt for, at det vil gå ud over deres barn.

I en undersøgelse af et kursus i 'den vanskelige forældresamtale' på en skole fandt Knudsen (2008a), at træningen begyndte med, at lærerne foretog en kategorisering af forskellige typer af vanskelige forældre. Lærerne brugte på denne skole fem kategorier: de ekstremt velforberedte, de egoistiske, de afglidende, de aggressive og det uenige forældrepar. Lærerne var enige om, at den sværeste forældretype at håndtere var den ekstremt velforberedte, fordi forældrene retter en tredobbelt kritik mod skolen: 1. De påberåber sig, at deres erfaring som forældre tæller lige så meget som lærerens, 2. De trækker på professionel viden, og 3 . De accepterer ikke, at lærernes normer for god elevadfærd er enerådende.

De såkaldt ekstremt velforberedte forældres kritik opleves som vanskelig, når skolen arbejder ud fra de fem diskurser, men ikke hvis skolen arbejder med responsivt forældresamarbejde. Her vil forældrenes kritik, bekymringer og forslag ses som en gave til skolen i skolens kontinuerlige arbejde med at forbedre praksis til gavn for alle børn. Vi må stoppe med at tale (og tænke) negativt om forældre. Næste skridt er at forholde sig kritisk til de fem diskurser, når de popper op i kommunikation, skriftligt såvel som mundtligt. Det er skolens ansatte, der er de professionelle, og dermed har de det formelle ansvar for at etablere et samarbejde, der er godt for begge parter. 


\section{Hvorfor lytte til forældrene?}

Oplevelsen af ikke at blive lyttet til er et gennemgående tema i forældres beretninger om skole-hjem-samarbejdet omkring børns skoleproblemer. Smyth \& Hattam understreger, at hvad der bliver sagt, og hvad der bliver lyttet til, altid bør ses som betinget af ulige magtrelationer (2004, s. 13). At være sensitiv over for magt indebærer responsivitet i forhold til, at følelser, positioner, relationer og handlinger formes gennem og med den kommunikation, som de, der besidder magt, udøver. I relation til skole-hjem-samarbejdet og det pædagogiske arbejde har skolens professionelle ikke kun det ansvar, der følger med deres professionelle position, men også en overmagt via deres faglighed og deres organisatoriske bagland. Overfor sidder børn og forældre, der nok kan udgøre en vanskelighed for skolens professionelle, men som sidder ved bordet uden formel magt, i rollen som privatperson, som mor, far, søn eller datter. Og som jeg har redegjort for, har de både juridisk ret til - og et almenmenneskeligt behov for - at blive hørt, ligesom vi i skolen har brug for at lære af det, som de fortæller os (se figur 2).

- Fordi de har ret til at blive hørt

- Fordi er er eksperter på deres barn og taler som indsigtsfulde ambassadører for deres barn

- Fordi deres barn har ret til et godt skoleliv med trivsel og læring, og forældrene kan bidrage med viden og input til skolens arbejde med at skabe det gode skoleliv

- Hvis ikke vi lytter, risikerer vi at gå glip af værdifuld viden

- Hvis ikke vi lytter, risikerer vi at gøre skade og skabe negative historier om skolen.

Figur 2. Grunde til at lytte til forældrene.

\section{De vigtige forældreperspektiver}

Forældreperspektiver på skolens praksis, herunder problemhåndtering, har traditionelt ikke været genstand for megen forskning (Freeman, 2010; Madsen, 2012), hvilket er mærkeligt, da skole-hjem-samarbejde er vurderet til at have stor betydning for elevers læring i skolen (Epstein, 2001; Hattie, 2009; Nordahl, 2008; Krogh \& Smidt, 2015). Når elevers og forældres perspektiver dømmes ude, har de ingen legitime "lyttere" at henvende sig til. At invitere forældreperspektiver ind er ikke kun en måde at legitimere 
disse perspektiver på, men peger også på vigtigheden af, at vi lytter mere opmærksomt til, hvad de siger. Hvis de ikke bliver inviteret indenfor, forbliver de tavse eller kritiske. Men gives de en legitim plads i dialogen, kan de bidrage med vigtige, væsentlige og værdifulde input til skolens praksis, som vi skal se om lidt. Når vi lytter til elev- og forældrestemmer, træder de frem som det, man med Foucault (1980) kan kalde subjugated knowers, og som Fine kalder constructors and agents of knowledge (1994, s. 75). Det, de siger, kaster lys over alt det, vi ikke vidste og ikke kunne se. Winslade \& Williams (2012) påpeger, at det at sige noget og bede om at blive hørt er en handling og et udtryk for agenthed og mod. Det er på tide at tage elev- og forældrestemmer mere alvorligt, hvilket betyder at give dem plads i hverdagens problemløsning og i forskning, men også i praktiske skoleudviklingsprojekter.

\section{Hvad forældre er vrede og kritiske over}

Når forældre fremstår vrede og kritiske, så har de typisk gode grunde til det. Forældre er opmærksomme på, om deres barn oplever sig som en del af skolens og klassens fællesskab. Det betyder noget for forældrene, at barnet kan deltage aktivt i skolens aktiviteter og undervisning, ligesom forældre er optagede af, at deres barn lærer noget i skolen og finder undervisningen engagerende og udbytterig. Når forældre rejser bekymring for deres barns skolegang, handler det typisk om et eller flere af sådanne forhold. Forældre ønsker, at skolens praksis og indsatser øger deres barns skoleglæde og lyst til at komme i skole, og skolen kan med fordel møde deres kritik med empati. I venstre side i skemaet nedenfor (figur 3) illustreres forældrenes ønsker til skolens indsatser. I højre side ses nogle af de skoleerfaringer, som børn i skolemistrivsel gør sig i skolen, og som giver anledning til forældrenes bekymringer og kritik (Haslebo \& Lund, 2014; Lund, 2017).

Børns skoletrivsel er ikke kun vigtig for børnene, men i høj grad altså også for deres forældre. For både børn og forældre er det vigtigt, at skolen professionelt kan løse børns skoleproblemer i skolen på inkluderende måder, der styrker børnenes oplevelse af at høre til på skolen (Lund, 2020a). Hansen (2011) beskriver belonging som elevens høren til i klassefællesskabet og argumenterer for, at longing for belonging kan ses som et konstituerende vilkår for samspil i klassen. Thomas (2012) påpeger, at skolens professionelle er afgørende i forhold til, om elever føler, at de hører til i skolen. Dette er også vigtigt i forhold til at forebygge fravær og frafald, som forudsætter involvering af eleverne i udviklingen og vedligeholdelsen af en culture of belonging (Lund \& Winslade, 2018; Lund, 2020a). 


\begin{tabular}{|c|c|}
\hline $\begin{array}{l}\text { Inklusion Skoletrivsel } \\
\text { (belonging) }\end{array}$ & Eksklusion Skolemistrivsel \\
\hline $\begin{array}{l}\text { Forœeldres ønsker til sko- } \\
\text { lens indsatser er, at de: } \\
\text { øger deres barns lyst } \\
\text { til at komme i skole } \\
\text { (tilstedeværelse) }\end{array}$ & $\begin{array}{l}\text { Dét, som forceldre bekymrer sig over, er: } \\
\text { Børn, som bliver sendt uden for døren, i AKT, på skole- } \\
\text { lederens kontor eller hjem. Børn, der har det så skidt } \\
\text { i skolen, at de ikke vil i skole (får frataget retten til at } \\
\text { være fysisk til stede) }\end{array}$ \\
\hline $\begin{array}{l}\text { øger deres barns } \\
\text { følelse af fællesskab }\end{array}$ & $\begin{array}{l}\text { Børn, der opfattes som besværlige eller vanskelige af } \\
\text { skolens voksne. Børn, der ikke har venner i skolen, eller } \\
\text { børn, der har faglige udfordringer, fx keder sig eller } \\
\text { synes det er svært (marginalisering af børn i klassevæ- } \\
\text { relset) }\end{array}$ \\
\hline $\begin{array}{l}\text { øger deres barns aktive } \\
\text { deltagelse }\end{array}$ & $\begin{array}{l}\text { Børn, der oplever ikke at blive lyttet til, at blive ignore- } \\
\text { ret eller blive gjort grin med i klassen. Børn, der ople- } \\
\text { ver, at de ikke har ret til indflydelse, medbestemmelse } \\
\text { eller deltagelse (usynliggørelse, passificering) }\end{array}$ \\
\hline $\begin{array}{l}\text { øger deres barns høje } \\
\text { relevante læringsud- } \\
\text { bytte }\end{array}$ & $\begin{array}{l}\text { Undervisning, der ikke giver læringsudbytte, men } \\
\text { muligvis læring om andre ting. Det er svært at lære fx } \\
\text { matematik, hvis man er henvist til AKT-rummet i mate- } \\
\text { matiktimen (jeg er dum, læreren er ond, de andre kan } \\
\text { ikke lide mig). }\end{array}$ \\
\hline
\end{tabular}

Figur 3. Forældrenes ønsker til skolens indsatser og børnenes erfaringer med skolemistrivsel

\section{At se på skolen i et elevperspektiv formidlet af forældrene}

Forældre, der er bekymrede for deres barns skoletrivsel, tilbyder vigtige informationer om kvaliteten af det inkluderende læringsmiljø i klassen. Når de henvender sig med bekymring, efterspørger de i realiteten en professionel respons og villighed til at styrke barnets skoletrivsel. Og det har de legitime grunde til, der er formuleret i de tidligere nævnte rettighedsdokumenter. Inklusion er en rettighed og kan defineres som den dynamiske og vedvarende proces, hvori skolen øger mulighederne for 1) tilstedeværelse, 2) oplevelse af fællesskab, 3) aktiv deltagelse og 4) højt læringsudbytte for alle elever. I denne proces tages der særligt vare på de elever, som er i fare for marginalisering, eksklusion og lavt fagligt udbytte (Alenkær, 2012; Haslebo \& Lund, 2014).

Forældres bekymring eller kritik kan handle om pædagogisk praksis, læringsmiljøet i klassen, skolens problemhåndtering, undervisningens kvalitet m.m. Disse forhold er helt væsentlige for ethvert barns skoletrivsel og 
læringsudbytte, men er også forhold, der ligger helt uden for forældrenes indflydelse. Det er skolens professionelle, der træffer afgørelser herom, ikke forældrene. Men forældrene kan bidrage via formidling af barnets skoleerfaringer, hvilket kan hjælpe skolens professionelle med at se på skolen i et elevperspektiv (som formidlet af forældrene). Det gør fx en stor forskel for børns skoleerfaringer, om den pædagogiske praksis på skolen indlejrer sig $i$ en individ-, problem-, fejl- og mangeltænkning eller i en relations-, ressource- og mulighedstænkning, som illustreret nedenfor (figur 4) (Haslebo \& Lund, 2014; Lund, 2017; Lund \& Winslade, 2018).

\begin{tabular}{|c|c|c|}
\hline & $\begin{array}{l}\text { Individ-, problem-, fejl- og } \\
\text { mangeltænkning }\end{array}$ & $\begin{array}{l}\text { Relations-, ressource- og } \\
\text { mulighedstænkning }\end{array}$ \\
\hline $\begin{array}{l}\text { Uro i } \\
\text { klassen }\end{array}$ & $\begin{array}{l}\text { Hvem laver ballade? Hvornår? } \\
\text { Hvor tit og hvor meget? Hvorfor } \\
\text { gør de det? Hvad er der galt med } \\
\text { dem? Hvordan kan vi sanktionere } \\
\text { dem, så de ændrer deres adfærd? }\end{array}$ & $\begin{array}{l}\text { Hvordan kan vi forstå 'balladen' } \\
\text { fra barnets og andres perspek- } \\
\text { tiv? Hvordan kan vi iscenesætte } \\
\text { kontekster, hvor alle kan indgå og } \\
\text { bidrage konstruktivt? }\end{array}$ \\
\hline Mobning & $\begin{array}{l}\text { Hvem mobber? Hvem er offeret? } \\
\text { Hvem er medløbere? Hvor grov er } \\
\text { mobningen? Hvorfor mobber de? } \\
\text { Hvorfor bliver de mobbet? }\end{array}$ & $\begin{array}{l}\text { Hvordan kan vi iscenesætte } \\
\text { begivenheder, hvor eleverne kan } \\
\text { udvise kærlig omsorg, hjælpsom- } \\
\text { hed og anerkendelse af forskelle? }\end{array}$ \\
\hline Konflikter & $\begin{array}{l}\text { Hvem startede? Hvad skete der? } \\
\text { Hvorfor.....?? }\end{array}$ & $\begin{array}{l}\text { Hvordan kommer vi bedst muligt } \\
\text { videre herfra? Hvad vil det være } \\
\text { klogt og hensigtsmæssigt at gøre } \\
\text { nu? }\end{array}$ \\
\hline $\begin{array}{l}\text { Vanskeligt } \\
\text { forælder } \\
\text {-samarbej- } \\
\text { de }\end{array}$ & $\begin{array}{l}\text { Hvorfor er de så besværlige? } \\
\text { Hvorfor forstår de ikke, hvad vi } \\
\text { siger? Hvorfor modarbejder de } \\
\text { skolen? }\end{array}$ & $\begin{array}{l}\text { Hvad er de særligt optagede af? } \\
\text { Hvad er det, de prøver at fortælle } \\
\text { mig? Hvordan kan vi bedst muligt } \\
\text { komme videre herfra? }\end{array}$ \\
\hline
\end{tabular}

Figur 4. To forskellige pædagogiske tilgange

Skemaet illustrerer de centrale spørgsmål, som skolens praksis typisk vil udspringe af i de to tilgange. Mange forældre til børn i skoleproblemer efterspørger en praksis, hvor skolens professionelle iscenesætter kontekster for relationsudvikling blandt børnene eller mellem fx en bestemt lærer og barnet. Der vil selvfølgelig også kunne findes forældre, der efterspørger en praksis med udspring i modellens venstreside.

Den responsive lytning vil kunne hjælpe parterne til at finde en fælles forståelse for mulighederne for at øge barnets trivsel i skolen via justeringer i den pædagogiske praksis. 


\section{At møde kritik med empati}

Forældre i samarbejdsproblemer med skolen oplever deres egne reaktioner på skolens afvisning af deres bekymringer eller kritik som stærkt ydmygende. Det, de reagerer på, er den nedgørende positionering, som opstår i mødet med skolens afvisning, samt den negative positionering, som deres børn fanges i i skolens problemhåndtering (Lund, 2017; Nielsen et al., 2017). Frustrationen og vreden kan med Winslade \& Williams (2012) ses som en protest eller et tegn på agenthed og med Foucault (1980) som et tegn på ansigtstab og en respons på den afmagt, forældrene sættes i i situationen. Uanset, så er det som forælder meget vanskeligt at handle klogt, kompetent og værdigt, når ikke man bliver lyttet til. Når elever og forældre positioneres som negative, besværlige, forkerte eller problematiske, har de ingen legitime handlemuligheder. De kan intet sige, de har ingen magt og ingen indflydelsesmuligheder. Nogle forældre vælger i denne afmagt at klage til skolelederen, skolebestyrelsen, skolechefen, Børne- og ungechefen, byrådet eller ombudsmanden, eller gå til medierne for på den måde at få deres perspektiver bragt til torvs. Udover at disse handlemuligheder er uønskede set fra skolens (og samfundets) perspektiv, så indeholder de også store negative konsekvenser for familierne. Responsivt forældresamarbejde søger at tilbyde forældre nogle helt andre handlemuligheder, nemlig som samarbejdspartnere, bidragydere og ambassadører for elevers trivsel og perspektiver på skolens hverdag. Men det forudsætter - udover evnen til at håndtere og løse børns skoleproblemer hensigtsmæssigt - at skolen lytter relationelt til forældrenes beretninger om barnet og dets skolegang og tager deres kritik og bekymringer alvorligt. Og til dette mangler der - som argumenteret i det ovenstående - en brugbar diskurs om skole-hjem-samarbejde.

\section{På vej mod en ny diskurs: samarbejdsdiskursen}

Det responsive forældresamarbejde tilbyder en ny og dermed sjette diskurs, nemlig samarbejdsdiskursen, der rummer et større potentiale for et egentligt samarbejde end de fem dominerende diskurser. I lighed med disse giver samarbejdsdiskursen dog heller ikke svar på skole-hjem-samarbejdets "hvad", "hvor meget" eller "hvornår", men den anviser bedre veje til samarbejdets "hvordan", hvilket er et kærkomment bidrag til praksisfeltet. Med det responsive forældresamarbejde tilbydes parterne nye positioner og en ny samarbejdsrelation. For skolens professionelle, som arbejder med respon- 
sivt forældresamarbejde, vil følgende være afgørende indsatsområder (se figur 5).

- Lytning og lydhørhed

- Oprigtig interesse for elev- og forældreperspektiver

- Anerkendende udforskning (anerkendende spørgsmål)

- Optagethed af skolens praksis (kultur) og praksisudvikling (den lærende organisation)

- Relationsudvikling mellem børn i skolen og mellem barn og voksen i skolen (skolebelonging).

Figur 5. Indsatsområder for skolens professionelle

Dette hviler på nogle nyttige grundantagelser om forældre (se figur 6), som adskiller sig væsentligt fra de negative måder at tænke og tale om forældre på, som jeg redegjorde for indledningsvist.

- Alle forældre og elever har ressourcer, evner og kompetencer og er villige til at samarbejde, at dele ideer og få indflydelse.

- Alle forældre er eksperter på deres barn og taler som ambassadører for deres barn. Når forældre møder skolen med kritik, er det, fordi de reelt er bekymrede og kede af det, og de gør det ud fra et håb om at få hjælp.

- Forældre kan ikke gøres ansvarlige for det, der sker i skolen. Forældre kan ikke fjernstyre deres børn.

- Alle forældre vil det bedste for deres barn og gør det bedste for deres barn. Alle forældre er også optagede af elevgruppens trivsel og vil gerne bidrage til alle børns trivsel i skolen.

- Det er skolens ansvar at skabe rammerne og relationerne for alle børns trivsel og læring i skolen. Når børn ikke trives i skolen, er det primært skolens ansvar at iværksætte indsatser/handlinger, der kan bringe barnet tilbage i skoletrivsel.

- Forældre kan bidrage og hjælpe skolen, bl.a. ved at formidle barnets perspektiv på skolens praksisser, at dele erfaringer om, hvad der kan være hjælpsomt i forhold til barnet, samt at viderebringe anerkendelse til skolens professionelle for det, de gør, som barnet har fundet hjælpsomt.

Figur 6. Grundantagelser i responsivt forældresamarbejde. (Lund, 2017)

Der, hvor der tales om forældre som værende vanskelige, besværlige, kritiske, eller der, hvor samtaler og møder med forældre ses som noget, der skal overstås, eller, som Knudsen (2008a) finder, at det for de professionelle gælder 
om at stå sammen og ruste sig mod de allermest kritiske, vil det være op ad bakke. Forberedelsen til forældresamarbejdet begynder allerede i de måder, som skolens professionelle tænker og taler om samarbejdet og forældrene på (Haslebo \& Lund, 2014).

\section{Hvordan ser responsivt forældresamarbejde på en skole ud?}

Børn, der lærer noget og er glade for at gå i skole, giver glade forældre. Det responsive forældresamarbejde kan se ud på mange måder, men grundlæggende søger det at lytte til forældrene og bruge deres perspektiver til at forbedre skolens praksis. At drive en udvikling fremad i skolen er en stor opgave for skolens professionelle, men hvis forældrene inviteres ind i et lydhørt og imødekommende samspil med skolen, kan de blive medspillere frem for modspillere. Forældre kan både formidle vigtig viden om det, som deres børn finder værdifuldt og sjovt og spændende og godt, og om det, som vækker bekymring eller kritik. Begge slags feedback vil være vigtig for skolen. Nedenstående oversigt illustrerer noget af det, som responsivt forældresamarbejde indebærer (figur 7).

- Spørge til forældrenes dårligste oplevelser med skolen (også...)

- Samle forældreklager, fx for de seneste 3, 5 eller 7 år, og se på tendenser, mønstre og budskaber - indkredse forbedringspotentialer

- Møde kritik med empati (forståelse, lydhørhed, anerkendelse og handling)

- Løse børns skoleproblemer hurtigt og effektivt

- Være fleksible, være klar til at ændre på rammer, struktur, bemanding

- Have en effektiv trivselskultur med fokus på styrkelse af børns skoletrivsel

- Tilbyde alle børn tilpasset og engagerende undervisning og værdige fællesskaber

- Have et aktivt og effektivt beredskab til håndtering af problemer og konflikter med forældre (baseret på formelle rettigheder, relationel etik, men også empati og kompetencer/faglighed)

Figur 7. Hvad responsivt forældresamarbejde på en skole kan indebære.

I et responsivt forældresamarbejde vil skolens ledelse, lærere og pædagoger bestræbe sig på at lægge møder med respekt for forældres arbejdstider, især i sager, der kalder på flere møder. Man vil erstatte 'bekymringsbreve' og 'bekymringsmøder' med andre benævnelser, fx 'dialogbrev' og 'idémøde' 
eller 'trivselsmøde', og man vil erstatte indkaldelse med invitation. Man vil i samarbejde med forældrene udarbejde en dagsorden for mødet baseret på udforskning af forhåbninger, så der sammen skabes en kontekst for et godt møde. Er konteksten uklar, er det meget vanskeligt for parterne at handle kompetent. Skolens professionelle vil lede mødet responsivt med brug af en mødeskabelon, der strukturerer samtalen hensigtsmæssigt og former en positiv og genoprettende kommunikation med fokus på ideer til handlinger, der kan tænkes at afhjælpe problemstillingen. Hvis barnet skal med til mødet, skal det nøje forberedes, hvordan dets stemme og perspektiv kan stå centralt, og hvordan mødet kan afholdes på en for barnet rar, respektfuld og tryg måde, som giver håb og positive selv- og fremtidsbilleder (Haslebo \& Lund, 2014; Lund, 2017).

\section{Inklusion gennem responsivt forældresamarbejde}

Det væsentlige er, at skolen inviterer forældrene ind i dialogen som vidende, respekterede og kloge. Dialogen skal handle om, hvordan skolen kan afhjælpe de problemer, som eleven er havnet i i skolen. Eleven skal ikke opfattes som problemet, og forældrene skal have mulighed for at bringe deres gode erfaringer og ideer til bords. Skolens professionelle skal lytte til og værdsætte eleven og forældrene. Gennem lydhørhed og villighed til at ændre på praksis udvikler de sammen et godt samarbejde med fokus på ideer og handlemuligheder, som skolen kan sætte i værk for at afhjælpe problemstillingerne. En sådan proces, inklusionsspiralen, er illustreret i Lund (2017) og gengives nedenfor (i figur 8).

\section{Vigtige kompetencer i responsive samtaler}

En central kvalitet i det responsive forældresamarbejde er de professionelles evne til at lede gode samtaler, dvs. at skabe samtalemæssige rum, hvor de sammen med forældrene motiveres gennem livgivende dialoger om de indsatser, som skolen kan iværksætte for at øge børns skoletrivsel og læringsglæde. Lader man indsatser til styrkelse af børns skoletrivsel og læring tage afsæt i forældres og elevers perspektiver og erfaringer, giver man samtidig afkald på definitionsretten. Det vil sige, at man giver afkald på at definere, hvordan den enkelte elev er, hvad problemet er og hvordan forældrene er. Skolens professionelle påtager sig derimod ansvaret for handling og intervention, men lader dette være informeret af forældre og elevers perspektiver, behov og drømme. Her spiller den professionelle en central rolle i at 
1. Skolen forstår, at eleven befinder sig i en problemstilling, og at de må gøre noget for at hjælpe

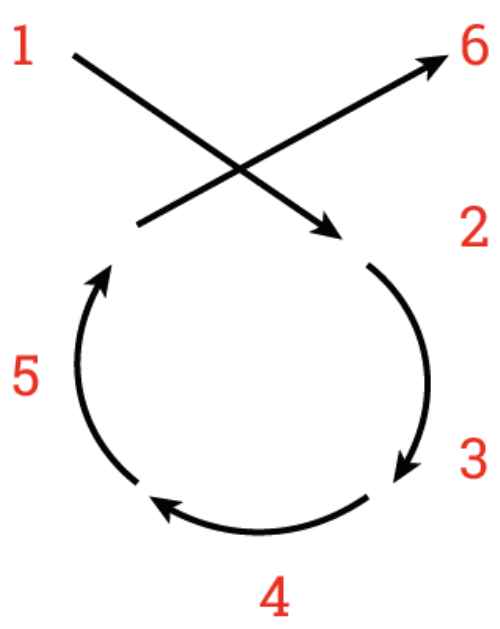

4. Skolen påtager sig ansvaret for at løse problemerne i skolen
6. Inklusion. Familien kan se en vej frem og har håb for fremtiden

2. Skolen beder forældrene om hjælp til at finde på løsninger, som skolen kan iværksætte for at hjælpe

3. Elev- og forældre-perspektiver bydes velkommen, lyttes til indgående, udforskes og påskønnes mellem skole og forældre

5. Skolen arbejder på a samt styrke samarbejdet således, at det ikke udvikler sig til samarbejdsvanskeligheder

Figur 8. Inklusionsspiralen

facilitere samtalen, så den særlige kvalitet ved en responsiv og udforskende tilgang giver ideer til handling, genopretter tillid til skolen og håb for barnets skolegang. Også skolens professionelle kan få gavn af et responsivt forældresamarbejde, når de besidder de kompetencer, som det bygger på. De vigtige kompetencer er:

(1) at kunne sætte en kontekst med ligeværdige positioner

(2) at lytte responsivt til forskellige (og afvigende, kritiske, besværlige) stemmer

(3) at være lydhør og villig til at lære nyt og handle på nye måder

(4) at kunne stille anerkendende, udforskende og narrative spørgsmål

(5) at kunne lede progression i en samtale

(6) at kunne mediere og genoprette relationer, der er blevet beskadiget

(7) at kunne samskabe en positiv opsummering af samtalens udbytte og omsætte denne til konkrete indsatser i skolen.

Herefter er det altafgørende, at skolens professionelle kan iværksætte indsatsen eller indsatserne, hvilket forudsætter kapacitet på skolen, viden om pædagogiske og didaktiske tiltag med mere. Jo bedre sådanne indsatser 
udtænkes og imødekommer de skoleproblemer, som børn kan komme i, des større succes for skolen, og dermed des gladere børn og forældre.

Det ville være en stor fordel, hvis ovenstående kompetencer indgik som en del af lærer- og pædagoguddannelsen samt skolelederuddannelserne. Kompetencerne er brugbare i enhver samtale, formel som uformel (Lund, 2015; Hansen-Skovmoes \& Rosenkvist, 2017). Det vil ikke kun øge sandsynligheden for, at den enkelte samtale bliver vellykket og udbytterig, men ganget op i forhold til de utallige samtaler, der afholdes på skoler mellem forældre og professionelle, vil den responsive tilgang på afgørende måder påvirke skolekulturen (Lund, 2020a, 2020b, 2020c).

\section{Opsummering}

Responsivt forældresamarbejde er et bidrag til at skabe et mere velfungerende og gensidigt tilfredsstillende skole-hjem-samarbejde. Dette med det formål, at skolens professionelle kan forbedre skolens måde at løse udfordringer på, både børns skoleproblemer og de udfordringer, der kan være i forbindelse med forældresamarbejdet. Et væsentligt element og formål med responsivt forældresamarbejde er at skabe læring om skolens praksis og kultur - og indkredse forbedringsmuligheder. Målet er at løse skoleproblemer hurtigt og effektivt og langtidsholdbart, så alle børns skolebelonging (trivsel, læring og tilhør) styrkes. Vejen går gennem udforskning sammen med forældre (og elever) af forskellige forhåbninger og ideer til indsatser, som skolen kan iværksætte. Tilfredse forældre og et godt samarbejde skaber flere positive historier om skolen og kan være med til at øge respekten for folkeskolen i offentligheden. Konkret søger responsivt forældresamarbejde at vende eksklusionsprocesser til inklusionsprocesser, således at skoleskift på grund af skoleproblemer kan undgås. Da forældrene ses som værdifulde bidragydere til skolens fortløbende udvikling og forbedring af praksis, og skolens professionelle ser kritik og bekymringer som læringsanledninger, tilbyder det responsive forældresamarbejde fundamentalt nye positioner for samarbejdet. Hermed anvises nye veje for skolens professionelle i arbejdet med at invitere alle slags forældre ind i en samarbejdsrelation som ligeværdige samarbejdspartnere, eksperter på eget barn og bidragydere til skolens udvikling af indsatser til styrkelse af alle børns trivsel og læring i skolen. Hermed søger det responsive forældresamarbejde at inddrage flere forældre end de sædvanligt opbakkende. 
I hverdagens skolepraksis kan man som lærer opleve at stå meget alene i forhold til at udvikle en praksis for samarbejdet med forældrene. Et forældresamarbejde præget af konflikt kan ødelægge arbejdsglæden og føre til sygemelding. Mange skoler formulerer forældresamarbejdet inden for de fem ubrugelige diskurser og har således ikke en hensigtsmæssig tilgang til forældresamarbejdet. Dette rammer den enkelte lærer, men er et skolekulturelt problem, og derfor lander den slags problemer også typisk på skolelederens bord. Arbejder skolelederen også inden for de fem diskurser, er ophør af samarbejdet med familien en nærliggende risiko.

\section{Referenser}

Alenkær, R. (2012). Den inkluderende skole. En grundbog. Frydenlund.

Akselvoll, M.Ø. (2018). Samspil mellem skole og hjem. Aarhus Universitetsforlag.

Bakhtin, M. (1986). Speech genres and other late essays. University of Texas Press.

Børne- og Socialministeriet (2018). Bekendtgørelse af lov om social service (Serviceloven). https://www.retsinformation.dk/forms/R0710.aspx?id=197036\#id835864ac-c049-4d43a1f3-21ae31b45377

Børne- og Undervisningsministeriet (2018). Bekendtgørelse af lov om folkeskolen. https://www. retsinformation.dk/Forms/R0710.aspx?id=196651

Børne- og Undervisningsministeriet (2018). Vejledning i forvaltningsret - for skoleledere. file://C:/Users/Forfatter/Downloads/191220-Vejledning-i-forvaltningsret-for-skoleledere.pdf ${ }^{* * *}$ denne reference peger på en lokal fil på forfatterens egen pc og ikke på hvor den er hentet ${ }^{* * *}$

Epstein, J. (2001). School, family, and community partnerships: Preparing educators and improving schools. Westview.

Folketingets Ombudsmands beretning, 2016.

http://www.ombudsmanden.dk/find/nyheder/alle/folkeskoler_glemmer_elevers_rettigheder/

Fine, M. (1994). Working the hyphens: reinventing self and other in qualitative research. I: Denzin, N., \& Lincoln, Y. (red.), Handbook of Qualitative Research (s. 70-82). Sage.

Foucault, M. 1980. Two lectures. I: Gordon, C. (red.), Power/knowledge: Selected interviews and other writings 1972-1977 by Michel Foucault. Pantheon Books.

FN's Børnekonvention af 20. nov. 1989. https://www.retsinformation.dk/forms/r0710. aspx?id=60837

Freeman, M. (2010). Knowledge is acting: 'Working-class parents' intentional acts of positioning within the discursive practice of involvement. International Journal of Qualitative Studies in Education, 23(2), 181-198. http://dx.doi.org/10.1080/09518390903081629

Dannesboe, K.I., Kryger, N., Palludan, C., \& Ravn, B. (2012). Hvem sagde samarbejde? Et hverdagslivsstudie af skole-hjem-relationer. Aarhus Universitetsforlag.

Den Europæiske Menneskerettighedskonvention af 4. nov. 1950. https://www.retsinformation.dk/Forms/R0710.aspx?id=60848

Hansen-Skovmoes, P., \& Rosenkvist, G. (2017). Samtaler i organisationer - veje til mening, læring og værdi i samtalepraksis. Hans Reitzels Forlag.

Hargreaves, A., \& Fullan, M. (2012). Professional capital: Transforming teaching in every school. Teachers College Press, Colombia University. 
Haslebo, G., \& Haslebo, M.L. (2007). Etik i organisationer. Fra gode hensigter til bedre handlemuligheder. Danske Psykologisk Forlag.

Haslebo, G., \& Lund, G.E. (2014). Relationsudvikling i Skolen. Dansk Psykologisk Forlag.

Haslebo, G., \& Lund, G.E. (2015). Practicing Relational Thinking in Dealing with Bullying in Schools. I: Dragonas, T., Gergen, K.J., McNamee, S., \& Tseliou, E. (red), Educations as Social Construction. TAOS Publications Worldshare.

Hattie, J.A.C. (2009). Visible learning. A synthesis of over 800 meta-analyses relating to achievement. Routledge Taylor \& Francis Group.

Knudsen, H. (2008a). Forældreledelse: Let's be careful out there! I: Sløk, C., \& Villadsen, K. (red.), Velfærdsledelse: Ledelse og styring I den selvstyrende velfærdsstat (s. 69-97). Hans Reitzels Forlag.

Knudsen, H. (2008b). Har vi en aftale? (U)mulighedsbetingelser for mødet mellem folkeskole og familie. Ph.d.-afhandling. Danmarks Pædagogiske Universitetsskole, Århus Universitet.

Knudsen, H. (2010). Har vi en aftale? - magt og ansvar i mødet mellem folkeskole og familie. Nyt fra samfundsvidenskaberne.

Krogh, S., \& Smidt, S.L. (2015). Forældresamarbejde, der virker. Dansk Psykologisk Forlag.

Lund, G.E., \& Haslebo, G. (2015). Kulturudvikling i skolen - hvordan? Dansk Psykologisk Forlag.

Lund, G.E. (2015). Socialkonstruktionisme i organisationer - kort fortalt. Dansk Psykologisk Forlag.

Lund, G.E. (2017). Making exclusionary processes in schools visible. Ph.d.-afhandling. University of Twente.

Lund, G.E. (2020a). Fravær i skolen kalder på relations- og kulturudvikling. Temanummer Frygt, Fravær og Frihed - når elever fravælger skole. Pædagogisk Psykologisk Tidsskrift, 57(1).

Lund, G.E. (2020b) (in print). Kulturudvikling - et spadestik dybere. Aktionsforskning i en folkeskole. I: Sunesen, M., Frimann, S., \& Jensen, J.B. (red.), Aktionsforskning i et læringsperspektiv (Kapitel 5). Hans Reitzels Forlag.

Lund, G.E. (2020c) (in print). Creating school harmony. I: McNamee, S., Gergen, M.M., Camargo Borges, C., \& Rasera, E. (red.), The SAGE Handbook of Social Constructionist Practice. Sage Publications.

Lund, G.E., \& Winslade, J.M. (2018). Responding to Interactive Troubles-Implications for School Culture. Wisdom in Education 8(1).

Madsen, A. (2012). Forældreinklusion - at gøre tynde historier tykkere. I: Alenkær, R. (red), Den inkluderende skole. En grundbog (s. 313- 339). Frydenlund.

McNamee, S., \& Gergen, K.J. (1999). Relational responsibility: Resources for sustainable dialogue. Sage.

Nordahl, T. (2008). Hjem og skole. Hvordan skaber man et bedre samarbejde? Hans Reitzels Forlag.

Nielsen, N., Vigild, P., \& Adolphsen, C. (2017). Retten til uddannelse. Når børn med handikap $i k k e$ går i skole. Institut for menneskerettigheder. Danmarks Nationale Menneske-rettighedsinstitution.

Ottosen, M.H., Andersen, D., Nielsen, L.P., Lausten, M., \& Stage, S.M.H. (2010). Børn og unge $i$ Danmark - Velfærd og triusel 2010. SFI - Det Nationale Forskningscenter for Velfærd. https://www.vive.dk/da/udgivelser/boern-og-unge-i-danmark-velfaerd-og-trivsel-2010-4318/

Roman, L.G. (1996). Spectacle in the dark: youth as transgression, display, and repression. Educational Theory, 46(1), 1-22.

Socialministeriet (2010). Handikapkonventionen. https://sim.dk/media/27543/fns-handicapkonvention-om-rettigheder-for-mennesker-med-handicap-paa-let-dansk.pdf 
Smyth, J., \& Hattam, R. (2004). Dropping out, Drifting off, Being excluded: Becoming somebody without school. Peter Lang.

Sibley, D. (1995). Geographies of exclusion: Society and difference in the West. Routledge.

Thastum, M. (2019). Skolefravær - udbredelse og forståelser. I: Skolens fraværende børn. Arsager og Indsatser. Dafolo Forlag.

Thomas, L. (2012). Building Student Engagement and Belonging in Higher Education at a time of change: final report from the What Works? Student Retention and Success programme. Higher Education Academy. https://www.heacademy.ac.uk/system/files/wh at_works_final_ report.pdf

Undervisningsministeriet (1994). Salamanca Erklæringen og Handlingsprogrammet for Specialundervisning. http://static.uvm.dk/Publikationer/1997/salamanca.pdf

Undervisningsministeriet (2012). Lov om ændring af lov om folkeskolen, lov om friskoler og private grundskoler m.v. og lov om folkehøjskoler, efterskoler, husholdningsskoler og håndarbejdsskoler (frie kostskoler) (Inklusionsloven). https:/www.retsinformation.dk/Forms/ R0710.aspx?id=141611

Undervisningsministeriet (2017). Undervisningsmiljøloven. https://www.retsinformation. $\mathrm{dk} /$ Forms/R0710.aspx?id=188636

Winslade, J., \& Williams, M. (2012). Safe and Peaceful Schools. Addressing Conflict and Eliminating Violence. Corwin Press. 